\title{
Variations of selected trace element contents in two layers of red deer antlers
}

\author{
Aleksandra Giżejewska ${ }^{1,2}$, Agnieszka Nawrocka ${ }^{3}$, Józef Szkoda ${ }^{3 \dagger}$, Jan Żmudzki \\ Jerzy Jaroszewski ${ }^{1}$, Zygmunt Giżejewski ${ }^{4}$ \\ ${ }^{1}$ Department of Pharmacology and Toxicology, ${ }^{2}$ Department of Veterinary Public Health Protection, \\ Faculty of Veterinary Medicine, University of Warmia and Mazury in Olsztyn, 10-719 Olsztyn, Poland \\ ${ }^{3}$ Department of Toxicology and Pharmacology, National Veterinary Research Institute, 24-100 Pulawy, Poland \\ ${ }^{4}$ Institute of Animal Reproduction and Food Research, \\ Polish Academy of Sciences, 10-748 Olsztyn, Poland \\ z.gizejewski@pan.olsztyn.pl
}

\begin{abstract}
Introduction: Hard antlers of deer are unique bioindicators of environmental metal pollutions, but sampling methods presented in the literature are inconsistent. Due to the specific growth pattern of antlers and their histological structure, sampling methods described in the literature were reviewed, the suitability of using mixed samples of both antler layers as element bioindicators was assessed, and the codified method of antler sampling used for bioindication was described. Material and Methods: Lead, cadmium, mercury, arsenic, copper, zinc, and iron in trabecular and cortical parts of hard antlers of red deer (Cervus elaphus) were determined using different methods of atomic absorption spectrometry (depending on the element). Results: Mean mercury content in trabecular bone $(0.010 \pm 0.018 \mathrm{mg} / \mathrm{kg})$ was 5 times higher than in cortical bone $(0.002 \pm 0.003$ $\mathrm{mg} / \mathrm{kg})$. Mean iron concentration was approximately 15 times higher in trabecular $(239.83 \pm 130.15 \mathrm{mg} / \mathrm{kg})$ than in cortical bone $(16.17 \pm 16.44 \mathrm{mg} / \mathrm{kg})$. Concentrations of other analysed elements did not differ statistically between antler layers. Conclusion: In mixed antler samples, concentrations of mercury and iron depend on the particular antler layer contents. This therefore warrants caution when comparing results across studies and specification of the sampling methodology of antlers is highly recommended.
\end{abstract}

Keywords: red deer, antler, environmental pollution, metal bioindication.

\section{Introduction}

Over the last two decades, the role of the environment in public health has increased, resulting in increased care for environmental protection. Lifestyle changes and pro-environmental activities call for appropriate monitoring of pollutant levels. Despite improvements such as wastewater treatment, gas and dust purification, metals production, and advances in processing and mining, significant amounts of toxic substances are still emitted to the environment (17). Persistent pollutants released in previous years remain of major concern as well $(8,22)$.

Apart from current environment status evaluation, an important element of environmental monitoring is the assessment of the effectiveness of applied remediation methods and contaminant emission control. Observation of changes in the levels of pollutants in each environmental compartment is necessary for planning further activities. Chemical compounds which are non- or not readily biodegradable are of special concern. This group of pollutants includes toxic elements like lead $(\mathrm{Pb})$, cadmium $(\mathrm{Cd})$, mercury $(\mathrm{Hg})$, and arsenic (As), which even in small doses can exert adverse effects on organisms (19).

Biomonitoring provides information about changes in the environment over the years based on the analysis of biological material (21). Samples of ice (8), tree ring (3), raised bog (17), river and lake sediments (23), as well as crustaceans and molluscs (1) are used for retrospective studies. A limitation of such samples is the inability to determine their precise date of origin in order to observe annual changes in pollutant levels (29). 
In contrast, cervid antlers have a number of advantages that make them a suitable and unique material for biomonitoring (6). Antlers are bony cephalic appendages which are cast and regenerated annually. During species-specific growing period, antlers accumulate environmental pollutants because of high demand for minerals (15). Sampling of naturally cast antlers is non-invasive, and antlers are also readily available when collected as trophies by hunters. Also, cervids have defined individual home-ranges and are widespread, so antlers are available over large areas and results of toxicological investigations can be applied to a particular region (24).

Studies on roe deer (Capreolus capreolus) and red deer (Cervus elaphus) confirmed the value of antlers as bioindicators of metals $(6,11,27)$ and radionuclide pollution in the environment (2). Furthermore, research demonstrated a decrease in antler lead and fluoride concentrations in recent decades correlating with their levels in the environment $(9,13)$, showed that element levels in antlers are associated with diet and physiological condition of animals (18), compared pollutants concentrations among regions (12), and analysed changes over time in one area (6).

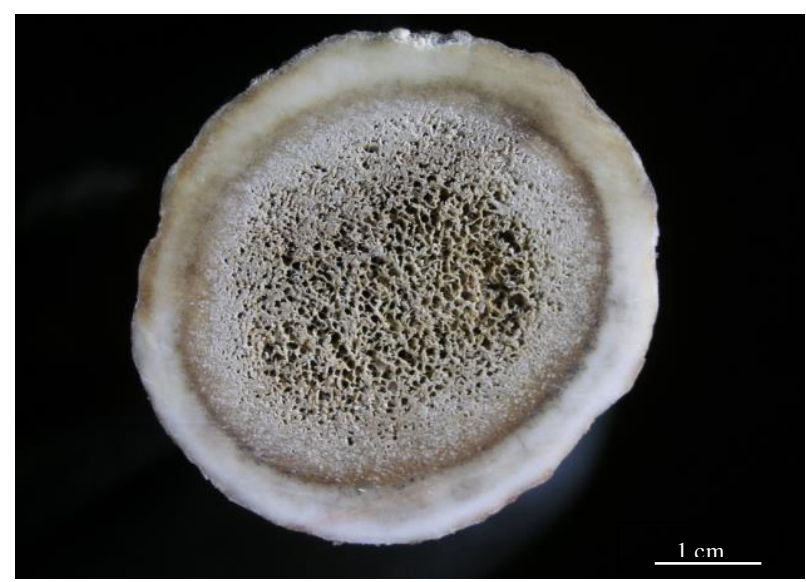

Fig. 1. Cross section of a hard red deer antler (photograph by Z. Giżejewski)

Hard antler is made up of two structurally distinct bony layers: an inner part - trabecular bone, and an outer part - cortical bone (Fig. 1), similarly to skeletal bone (16). To our knowledge, there are no studies describing the relationships of element concentrations between trabecular and cortical antler bone. To address this research gap, we determined concentrations of $\mathrm{Pb}, \mathrm{Cd}$, $\mathrm{Hg}$, As, copper $(\mathrm{Cu})$, zinc ( $\mathrm{Zn})$, and iron $(\mathrm{Fe})$ in inner and outer layer of red deer antlers, assessed the suitability of using mixed (both antlers layers) samples as bioindicators, discussed antler sampling methods described in the literature, and described the codified sampling method of antlers used for bioindication.

\section{Material and Methods}

Study area. Antlers from well-documented collection at the research station of the Polish Academy of Sciences in Popielno, Warmian-Masurian region, NE Poland $\left(21^{\circ} 38^{\prime} \mathrm{E}, 53^{\circ} 42^{\prime} \mathrm{N}\right)$, were used. This station is situated on a peninsula, surrounded by three lakes. This traditional agricultural area is covered mostly by mixed coniferous forest with a predominance of Scots pine. Climate is typically temperate with significant influence of the continental climate of Eastern Europe. The region is a popular touring place, located away from the large industrial centres $(7,23)$.

Sampling. Hard antlers were chosen randomly from 11 red deer stags. These antlers were cast between 1953 and 2012, when animals were exposed to different levels of metal pollution (6). Two samples were collected from each antler: one containing cortical bone and one containing trabecular bone. Antler samples (about 5-10 g; Fig. 2) were taken after manually cleaning the beam with nylon brush from surface contaminants. For sampling, rechargeable hand drill with vanadium drill (6 $\mathrm{mm}$ in diameter) was used. Samples of trabecular bone were obtained by drilling through the central part of antlers previously cut transversally upon the burr. Samples containing only cortical antler bone were obtained by drilling few shallow holes at the basis of the antler. After sample collection, the drill was rinsed with distilled water to avoid any secondary contamination.

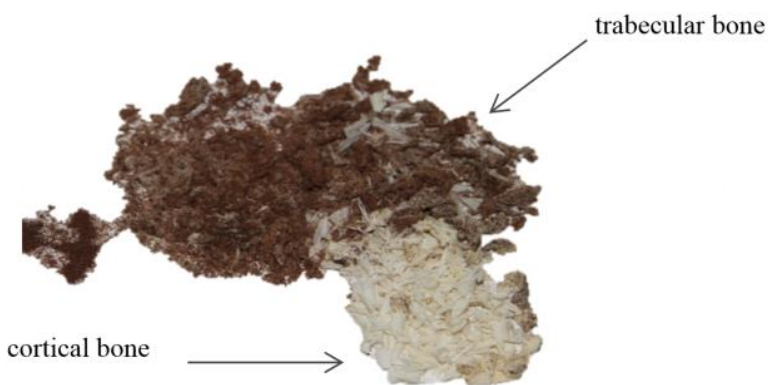

Fig. 2. Differences between trabecular and cortical bone samples (photograph by A. Giżejewska)

Chemical analysis. All samples were homogenised and then mineralised in a muffin furnace at $450^{\circ} \mathrm{C}\left(550^{\circ} \mathrm{C}\right.$ for As $)$ for $24 \mathrm{~h}$. Ashed samples were dissolved in $1 \mathrm{~N} \mathrm{HCl}$ (4.5N for As). Atomic absorption spectrometer Perkin-Elmer PinAAcle 900T was used to perform graphite furnace atomic absorption spectrometry determining $\mathrm{Pb}$ and $\mathrm{Cd}$ concentrations. The wavelength for $\mathrm{Pb}$ analysis was $283.3 \mathrm{~nm}$ and for $\mathrm{Cd}-228.2 \mathrm{~nm}$. Limit of quantitation (LOQ) for $\mathrm{Pb}$ and Cd was $0.002 \mathrm{mg} / \mathrm{kg}$ and $0.001 \mathrm{mg} / \mathrm{kg}$, respectively. Total $\mathrm{Hg}$ concentrations were determined by atomic absorption spectrometry method using direct mercury analyser AMA-254 (Altec, Czech Republic) without previous sample mineralisation. LOQ for $\mathrm{Hg}$ was established at $0.001 \mathrm{mg} / \mathrm{kg}$ with $253.7 \mathrm{~nm}$ wavelength. Hydride generation atomic absorption spectrometer PinAAcle 900T (Perkin Elmer, USA) was used for As determination. Arsenic analysis was performed with the wavelength set at $193.7 \mathrm{~nm}$ and LOQ was $0.002 \mathrm{mg} / \mathrm{kg}$. Concentrations of $\mathrm{Cu}, \mathrm{Zn}$, and $\mathrm{Fe}$ were determined 
using flame atomic absorption spectrometry with acetylene/air flame (AVANTA PM, GBC, USA). Wavelength for $\mathrm{Cu}, \mathrm{Zn}$, and $\mathrm{Fe}$ analysis was: $324.7 \mathrm{~nm}$, $213.9 \mathrm{~nm}$ and $248.3 \mathrm{~nm}$, respectively. LOQ was established at $0.04 \mathrm{mg} / \mathrm{kg}$ for $\mathrm{Cu}, 0.12 \mathrm{mg} / \mathrm{kg}$ for $\mathrm{Zn}$, and $0.11 \mathrm{mg} / \mathrm{kg}$ for Fe.

Determination of the seven elements was based on calibration curves plotted from working standard solutions and blanks. Limit of detection and LOQ were calculated as 3 to 10 times SD from values for blank matrix measurements with a low content of analyte. Reagent blanks and control samples were prepared and run in triplicate. Calibration curves were verified every $20^{\text {th }}$ reading by analysing the standard.

Quality control of the methods was performed using certified reference materials (CRM's): TORT-2 (lobster hepatopancreas), BCR 150 (skimmed milk powder), BCR 185R (bovine liver), and ERM-CD 281 (rye grass). Results of CRM's analysis are given in Table 1.

Statistical analysis. Element concentrations were expressed in micrograms per gram of dry weight $(\mathrm{mg} / \mathrm{kg}$ d.w.) and reported as arithmetic means, standard deviations (SD), median, and range (Table 2). Concentrations below LOQ were assigned a value of half the LOQ for that element.
For each element, differences in concentrations between inner and outer layer of antler were tested using pairwise Wilcoxon test. This analysis was performed on 22 samples (11 compact bone and 11 trabecular bone paired samples). Statistical significance was set at $\mathrm{P}<0.05$. All statistical analyses were conducted using $\mathrm{R}$ statistical software (version 3.2.0).

\section{Results}

To confirm the suitability of using mixed antler samples for bioindication research, the concentrations of seven elements between the two bony layers of antlers were compared. All results are presented in Table 2. Higher concentrations in trabecular than in cortical layer were found for $\mathrm{Hg}$ and $\mathrm{Fe}$. Mercury content in trabecular bone $(0.010 \pm 0.018 \mathrm{mg} / \mathrm{kg}$, $<0.001-0.062 \mathrm{mg} / \mathrm{kg}$ ) was five times higher than in cortical bone $(0.002 \pm 0.003 \mathrm{mg} / \mathrm{kg},<0.001-0.010 \mathrm{mg} / \mathrm{kg}$; $\mathrm{T}=0.0 ; \mathrm{P}=0.012)$. Iron concentration in trabecular layer $(239.83 \pm 130.15 \mathrm{mg} / \mathrm{kg}, 123.87-556.57 \mathrm{mg} / \mathrm{kg})$ was approximately 15 times higher than in cortical bone $(16.17 \pm 16.44 \mathrm{mg} / \mathrm{kg}, 6.37-54.84 \mathrm{mg} / \mathrm{kg} ; \mathrm{T}=0.0$; $\mathrm{P}=0.003$ ). Concentrations of $\mathrm{Pb}, \mathrm{Cd}, \mathrm{As}, \mathrm{Cu}$, and $\mathrm{Zn}$ in both antler layers were similar and did not differ statistically (Table 2).

Table 1. Results of certified reference material analyses

\begin{tabular}{ccccc}
\hline $\begin{array}{c}\text { Reference } \\
\text { material }\end{array}$ & Element & $\begin{array}{c}\text { Assigned value } \\
(\mathrm{mg} / \mathrm{kg})\end{array}$ & $\begin{array}{c}\text { Measured value } \\
(\mathrm{mg} / \mathrm{kg})\end{array}$ & Recovery $(\%)$ \\
\hline \multirow{5}{*}{ TORT-2 } & $\mathrm{Pb}$ & $0.35 \pm 0.13$ & 0.324 & 91 \\
& $\mathrm{Cd}$ & $26.7 \pm 0.6$ & 24.47 & 92 \\
& $\mathrm{Hg}$ & $21.6 \pm 1.8$ & 0.305 & 113 \\
& $\mathrm{As}$ & $106.0 \pm 10.0$ & 20.86 & 96 \\
& $\mathrm{Cu}$ & $180.0 \pm 6.0$ & 102.44 & 97 \\
& $\mathrm{Zn}$ & $105.0 \pm 13.0$ & 197.19 & 96 \\
\hline \multirow{3}{*}{ BCR 150 } & $\mathrm{Fe}$ & $1.000 \pm 0.040$ & 101.3 & 105 \\
& $\mathrm{~Pb}$ & $0.022 \pm 0.001$ & 0.021 & 98 \\
& $\mathrm{Cd}$ & $0.009 \pm 0.002$ & 0.011 & 117 \\
\hline \multirow{3}{*}{ BCR 185R } & $\mathrm{Hg}$ & $0.172 \pm 0.009$ & 0.174 & 98 \\
& $\mathrm{~Pb}$ & $0.544 \pm 0.017$ & 0.537 & 106 \\
\hline & $\mathrm{Cd}$ & $0.033 \pm 0.002$ & 0.035 & 93 \\
& $\mathrm{As}$ & $1.670 \pm 0.110$ & 1.551 & 91 \\
ERM-CD 281 & $\mathrm{Pb}$ & $0.120 \pm 0.007$ & 0.109 & 107 \\
& $\mathrm{Cd}$ & $0.016 \pm 0.002$ & 0.017 & 82 \\
\hline
\end{tabular}

Table 2. Concentrations ( $\mathrm{mg} / \mathrm{kg}$ ) of selected elements in trabecular (inner) and cortical (outer) layers in red deer antlers and results of pairwise Wilcoxon tests. Statistical significance was set at $\mathrm{P}<0.05$

\begin{tabular}{ccccccccccccccc}
\hline \multirow{2}{*}{ Element } & $\mathrm{n}$ & \multicolumn{3}{c}{ Trabecular bone } & \multicolumn{3}{c}{ Cortical bone } \\
\cline { 3 - 8 } & & Mean \pm SD & Median & Range & Mean \pm SD & Median & Range \\
\hline $\mathrm{Pb}$ & 11 & $0.551 \pm 0.21$ & 0.554 & $0.260-0.945$ & $0.558 \pm 0.199$ & 0.49 & $0.279-0.924$ & 19.5 & 0.415 \\
$\mathrm{Cd}$ & 11 & $0.006 \pm 0.002$ & 0.007 & $0.003-0.009$ & $0.008 \pm 0.004$ & 0.008 & $0.005-0.019$ & 19.5 & 0.415 \\
$\mathrm{Hg}$ & 11 & $0.010 \pm 0.018$ & 0.004 & $<0.001-0.062$ & $0.002 \pm 0.003$ & 0.001 & $<0.001-0.010$ & 0.0 & $0.012^{*}$ \\
$\mathrm{As}$ & 11 & $0.018 \pm 0.009$ & 0.014 & $0.010-0.037$ & $0.024 \pm 0.027$ & 0.017 & $0.005-0.103$ & 22.0 & 0.953 \\
$\mathrm{Cu}$ & 11 & $1.82 \pm 0.6$ & 1.74 & $0.99-2.54$ & $1.74 \pm 0.81$ & 1.64 & $0.49-3.04$ & 28.0 & 0.657 \\
$\mathrm{Zn}$ & 11 & $62.31 \pm 8.5$ & 63.09 & $51.36-78.9$ & $63.43 \pm 10.99$ & 63.43 & $50.33-90.04$ & 32.0 & 0.929 \\
$\mathrm{Fe}$ & 11 & $239.83 \pm 130.15$ & 197.02 & $123.87-556.57$ & $16.17 \pm 16.44$ & 9.09 & $6.37-54.84$ & 0.0 & $0.003 *$ \\
\hline
\end{tabular}

$\mathrm{T}$ - value of pairwise Wilcoxon tests 


\section{Discussion}

The most common method of antler sampling for studies regarding environmental contamination analysis is described by Tataruch (28). It consists of drilling a hole into the back of the antler beam at the height of the brow tine, and collecting approximately $1 \mathrm{~g}$ of cortical bone. This method was modified by Kierdorf and Kierdorf (13), who drilled deeper into the main beam obtaining both antler layers, or drilled several holes in the antler basis collecting only cortical bone as a result (12). In previous studies, authors included the information about the height of drilling on the beam but not about sample composition (11, 26, 27). The described methods of antler sampling provide the potential differences of element contents between the outer and inner antler part. This needs to be taken into account for accurate interpretation of the results and precise comparison of data available in the literature. To our knowledge, this study is the first describing the impact of the antler sampling method on element concentrations.

We demonstrated higher $\mathrm{Hg}$ and $\mathrm{Fe}$ levels in trabecular than cortical antler layer. Bone tissue is not the target accumulation place for $\mathrm{Hg}$ in organism. Higher concentration of this element in trabecular antler bone is probably the effect of specific blood supply in a growing antler, and $\mathrm{Hg}$ present in blood during this period as well as limited transfer to cortical bone. Consistently, significantly higher $\mathrm{Fe}$ concentration in trabecular bone than cortical one is likely caused by the presence of blood residues (Fe being a component of haem). Muir et al. (20) hypothesised that fluoride and $\mathrm{Pb}$ transport to the forming antler is not a continuous process but is more intense in the last phase of growing. During the last 10 weeks of antler growth, when tissue mineralisation is the most intense, approximately $65 \%$ of the total amount of the mineral is supplied $(14,20)$.

Blood is supplied to a growing antler in two ways. The major blood source of the antler are the vessels situated under velvet; negligible blood is supplied through the pedicle and is maintained until the ossification of the basis is finished (10). Nevertheless, after velvet shedding both trabecular and cortical bone of the antler main beam are still supplied almost until casting by vessels and capillaries at the basis (25). This is probably the reason for higher $\mathrm{Fe}$ and $\mathrm{Hg}$ concentrations in trabecular bone. Contrary to other analysed elements, $\mathrm{Hg}$ and $\mathrm{Fe}$ transfer less into mineralised tissue $(5,6)$.

There are few studies concerning antlers as bioindicator of environmental $\mathrm{Hg}$ contamination. In antlers concentration of this element is low; however, in roe deer antlers from north-western (5) and southwestern Poland (4) $\mathrm{Hg}$ levels were higher than those detected in our study. This likely reflects animal exposure to $\mathrm{Hg}$-containing pollutants during antler growth.
Landete-Castillejos et al. (18) compared chemical composition of red deer antlers collected in central and southern Spain in areas under different management regimes. These authors showed similar $\mathrm{Fe}$ values to those obtained in our study in the cortical bone samples in all compared areas. Jabłońska et al. (9) pointed to a wide range of $\mathrm{Fe}$ concentrations (from $99 \mathrm{mg} / \mathrm{kg}$ to $553 \mathrm{mg} / \mathrm{kg}$ ) in roe deer antlers from southern Poland, likely due to various content of trabecular antler bone in mixed samples.

The differences in the levels of other analysed elements were not significant between inner and outer antler layers. This indicates the ability to determine the concentrations of $\mathrm{Pb}, \mathrm{Cd}, \mathrm{As}, \mathrm{Cu}$, and $\mathrm{Zn}$ in any type of antler samples, i.e. mixed samples (containing both parts), samples of trabecular bone, or samples of cortical bone only. Therefore, accurate interpretation of results and comparison with the literature data can be obtained. This conclusion is especially important for monitoring of toxic elements. We suggest analysing those two layers separately for $\mathrm{Hg}$ and $\mathrm{Fe}$ concentrations, since in the case of mixed samples the content of these elements will depend on a particular layer of the antler.

Further investigation of other contaminants in cervid antlers, comparison between trabecular and cortical layers, and relations among them is necessary to draw further conclusions about the impacts of the sampling method on the bioindication value of antlers. Due to the specific patterns of growth in different antler parts and their particular chemical composition, it is also important to investigate variability of element concentrations in samples taken at different heights of the beam.

Conflict of Interests Statements: The authors declare that there is no conflict of interests regarding the publication of this article.

Financial Disclosure Statement: This study was funded by the Polish Ministry of Science and Higher Education and is the first part of series of papers considering red deer antlers as environmental bioindicators.

Animal Rights Statement: None required.

Acknowledgements: We would like to thank Jarosław Kozak and Dr Maciej Durkalec for their assistance in chemical analysis. Special thanks to J. Fattebert for his help with statistical analyses and language guidance.

\section{References}

1. Abdel-Salam H.A., Hamdi S.A.H.: Heavy metals monitoring using commercially important crustaceans and mollusks collected from Egyptian and Saudi Arabia coasts. Anim Vet Sci 2014, 2, 49-61. 
2. Baeza A., Vallejo I., Guillén J., Salas A., Corbacho J.A.: Antlers of Cervus elaphus as biomonitors of ${ }^{90} \mathrm{Sr}$ in the environment. J Environ Radioact 2011, 102, 311-315.

3. Baross N., Jordan G., Albert J., Abdaal A., Anton A.: Ecomonitoring of highly contaminated areas: historic heavy metal contamination in tree ring records. Geophys Res Abstr 2014, 16, 15902.

4. Chyla A., Lorenz K., Gaggi C., Renzoni A.: Pollution effects on wildlife: roe deer antlers as non-destructive bioindicator. Environ Prot Eng 1996, 3, 65-70.

5. Dobrowolska A.: Chemical composition of the red deer (Cervus elaphus) antlers, with a particular reference to the toxic metal contents. Z Jagdwiss 2002, 48, 148-155.

6. Giżejewska A.: Contamination of selected elements in red deer (Cervus elaphus) antlers as an indicator of environmental pollution. $\mathrm{PhD}$ thesis, University of Warmia and Mazury, Olsztyn, Poland, 2015 (in Polish with English summary).

7. Giżejewska A., Spodniewska A., Barski D., Fattebert J.: Beavers indicate metal pollution away from industrial centres in northern Poland. Environ Sci Pollut R 2015, 22, 3969-3975.

8. Hong S., Candelone J.P., Pettersson C.C., Boutron C.F.: Greenland ice evidence of hemispheric lead pollution two millennia ago by Greek and Roman civilizations. Science 1994, 265, 1841-1843.

9. Jabłońska M., Kramarczyk M., Smieja-Król B., Janeczek J.: Barium concentration in cast roe deer antlers related to air pollution caused by burning of barium-enriched coals in southern Poland. Environ Sci Pollut R 2016, 23, 5978-5982.

10. Jaczewski Z.: Antlers of cervids. PWRiL 1992, Warsaw, Poland (in Polish).

11. Kardell L., Källman S.: Heavy metals in antlers of roe deer from two Swedish forests. Ambio 1986, 15, 232-235.

12. Kierdorf U., Kierdorf H.: Assessing regional variation of environmental fluoride concentrations in western Germany by analysis of antler fluoride content in roe deer (Capreolus capreolus). Arch Environ Contam Tox 2002, 42, 99-104.

13. Kierdorf H., Kierdorf U.: The use of antlers to monitor temporal variation in environmental lead levels: a case study from an industrialized area in Germany. Eur J Wild Res 2004, 50, 62-66.

14. Kierdorf U., Kierdorf H.: Antlers as biomonitors of environmental pollution by lead and fluoride: a review. Eur J Wildl Res 2005, 51, 137-150.

15. Kierdorf U., Kierdorf H.: Roe and red deer antlers as bioindicators of pollution of deer habitats by lead and fluoride. Vet Arhiv 2006, 76, 117-129.
16. Kierdorf U., Stoffels D., Kierdorf H.: Element concentrations and element ratios in antler and pedicle bone of yearling red deer (Cervus elaphus) stags - a quantitative X-ray fluorescence study. Biol Trace Elem Res 2014, 162, 124-133.

17. Küttner A., Mighall T.M., De Vleeschouwer F., Mauquoy D., Cortizas A.M., Foster I.D., Krupp E.: A 3300-year atmospheric metal contamination record from Raeburn Flow raised bog, south west Scotland. J Archaeol Sci 2014, 44, 1-11.

18. Landete-Castillejos T., Estevez J.A., Ceacero F., Garcia A.J., Gallego L.: Effects of public vs. private management on deer antler composition, mechanical and structural variables. Eur J Wildl Res 2013, 59, 519-529.

19. Lanocha N., Kalisinska E., Kosik-Bogacka D.I., Budis H., Sokolowski S., Bohatyrewicz A.: Comparison of metal concentrations in bones of long-living mammals. Biol Trace Elem Res 2013, 52, 195-203.

20. Muir P.D., Sykes A.R., Barrell G.K.: Growth and mineralisation of antlers in red deer (Cervus elaphus). New Zeal J Agr Res 1987, 30, 305-315

21. Pokorny B., Glinšek A., Ribarič-Lasnik C.: Roe deer antlers as a historical bioindicator of lead pollution in the Šalek Valley, Slovenia. J Atmos Chem 2004, 49, 175-189.

22. Pokorny B.: Roe deer (Capreolus capreolus L.) antlers as an accumulative and reactive bioindicator of lead pollution near the largest Slovene thermal power plant. Vet Arhiv 2006, 76, 131142.

23. Prosowicz D.: Metals in bottom sediments of Wigry Lake. Geologia/Akademia Górniczo-Hutnicza im. Stanisława Staszica in Krakow. 2008, 34, 85-108.

24. Reinecke H., Leinen L., Thißen I., Meißner M., Herzog S., Schütz S., Kiffner C.: Home range size estimates of red deer in Germany: environmental, individual and methodological correlates. Eur J Wildl Res 2014, 60, 237-247.

25. Rolf H.J., Enderle A.: Hard fallow deer antler: a living bone till antler casting? Anat Rec 1999, 255, 69-77.

26. Samiullah Y., Jones K.C.: Deer antlers as pollution monitors in the United Kingdom. Global trends wildl management 1991, 1, 415-420.

27. Sawicka-Kapusta K.: Roe deer antlers as bioindicators of environmental pollution in southern Poland. Environ Pollut 1979, 19, 283-293.

28. Tataruch F.: Red deer antlers as biomonitors for lead contamination. Bull Environ Contam Toxicol 1995, 55, 332-337.

29. Weiss D., Shotyk W., Kempf O.: Archives of atmospheric lead pollution. Naturwissenschaften 1999, 86, 262-275. 